\title{
REVIEW: APPLICATION OF IRRADIATION TECHNOLOGY IN NATURAL RUBBER VULCANIZATION PROCESS
}

\author{
Andri Saputra ${ }^{1^{*}}$ \\ 1) Department of Rubber and Plastics Processing Technology, Politeknik ATK \\ Yogyakarta, Indonesia 55187 \\ *Corresponding author: andri.saputra@atk.ac.id
}

\begin{abstract}
ABSTRAK
APLIKASI TEKNOLOGI IRADIASI DALAM PROSES VULKANISASI KARET ALAM. Teknologi vulkanisasi perlu dikembangkan untuk menghilangkan beberapa potensi dampak negatif dari vulkanisasi konvensional seperti mengandung nitrosamin dan protein alergen yang berbahaya bagi kesehatan, residu toksik senyawa akselerator, tidak dapat dilakukan pada suhu kamar, dan ikatan silang belerang berkontribusi terhadap dampak asifikasi. Salah satu teknologi maju yang dapat digunakan dalam pengolahan polimer, seperti karet alam, adalah iradiasi menggunakan sinar gamma. Kajian review ini bertujuan untuk mengkaji bagaimana proses vulkanisasi iradiasi, dosis radiasi yang digunakan, dan pengaruhnya terhadap sifat kuat tarik produk karet berdasarkan referensi dari buku dan jurnal bereputasi nasional dan internasional. Radiasi pada lateks karet alam akan menyebabkan pembentukan radikal bebas, ikatan silang, dan pemutusan rantai antar rantai poliisoprena, serta sebagian besar menghasilkan gas $\mathrm{H}_{2}$. Untuk pengikatan silang, bahan dengan rasio $G(S): G(X)<1,00$ lebih disukai. Peningkatan dosis hingga dosis tertentu menyebabkan peningkatan densitas ikatan silang karet yang diiradiasi, sementara ternyata mekanisme degradasi telah terjadi pada dosis yang lebih besar dari dosis optimum. Kekuatan tarik putus radiasi vulkanisat telah lama dianggap lebih rendah daripada vulkanisasi belerang atau peroksida vulkanisat. Pendekatan untuk meningkatkan ikatan silang radiasi dapat didefinisikan dengan penggabungan dengan pengisi, meningkatkan kemungkinan rekombinasi radikal polimer, dan meningkatkan jumlah radikal polimer.
\end{abstract}

Kata kunci : iradiasi, karet alam, vulkanisasi

\section{ABSTRACT}

APPLICATION OF IRRADIATION TECHNOLOGY IN NATURAL RUBBER VULCANIZATION PROCESS. A vulcanization technology needs to be developed in order to eliminate some potentially negative impacts of conventional vulcanization such as contain nitrosamines and allergen proteins that are harmful to health, toxic residues of accelerator compound, cannot be done at room temperature, and sulfur crosslinking contribute to acidification impact. One of the advanced technologies that can be used in the processing of polymers, such as natural rubber, is irradiation using gamma rays. This review study aims to examine how the irradiation vulcanization process, the radiation dose used, and its effect on the tensile strength properties of rubber products based on references from books and journals of national and international reputation. Radiation in latex of natural rubber will cause free radical formation, crosslinking, and chain scission between polyisoprene chains, and also produce mostly $\mathrm{H}_{2}$ gas. For crosslinking, materials with $G(S): G(X)$ ratios $<1.00$ are preferred. The dose increase till a certain dose led to an increase in the cross-link density of the irradiated rubbers, while apparently, the degradation mechanism has occurred for doses greater than optimum doses. The tensile strength at break of radiation vulcanizate has long been presumed to be lower than that of sulfur vulcanizate or peroxide vulcanizate. The approaches for enhancing radiation crosslinking could be defined by incorporation with filler, increasing the possibility of polymer radical recombination, and increasing the number of polymer radicals.

Key words: irradiation, natural rubber, vulcanization

\section{INTRODUCTION}

One of the plantation commodities which has a very important role in Indonesia is natural rubber. Indonesia is the second biggest natural rubber manufacturer within the global after Thailand [1]. For Indonesia, rubber plays a role 
as a source of income and employment for the population, a source of foreign exchange from non-oil and gas exports, and can encourage the growth of agro-industry in the fields of plantations, biological resources, and environmental conservation [2]. Indonesian natural rubber production increased by $2.81 \%$ from 3.45 million tonnes in 2019 , to 3.55 million tonnes in 2020. The projection results using multiple regression, rubber production in 2020 to 2024 will experience an average increase of $1.75 \%$ per year [3]. Compared to synthetic rubber, natural rubber is more environmentally friendly, both in terms of the supply of raw materials and in the production process [4]. In addition, petroleum price sharply increasing in the international market has caused the demand for natural rubber to increase rapidly. It is caused by synthetic rubber whose raw material comes from the petroleum fraction has also increased in price [5].

Natural rubber latex has uses as a raw material for producing tires, balls, shoes, gloves, swimwear, rubber bands, rubber toys, medical goods, and various other downstream products [6]. The downstream rubber product is produced through several stages of the process. The main process in processing natural rubber latex is the process of forming chemical crosslinks from independent molecular chains known as vulcanization. This process can increase elasticity and decrease plasticity.

Vulcanization nowadays has been performed by chemical or conventional methods using chemicals, such as zinc oxide, stearic acid, dithiocarbamates as an accelerator, antioxidants, fillers, and plasticizers, and mainly sulfur as a crosslinking agent [7]. Rubber products from conventional vulcanization contain residues of accelerator compound, such as dithiocarbamates, which are also thought to be toxic to rubber decomposing bacteria and are not environmentally friendly. In addition, environmentally friendly rubber products from sulfur vulcanization are burned or burned, producing sulfur dioxide gas $\left(\mathrm{SO}_{\mathrm{x}}\right)$ which is harmful to health and the environment [4]. Conventional vulcanization also cannot be done at room temperature because the process is carried out by three times heating, namely heating at $40-50{ }^{\circ} \mathrm{C}$ for $2-3$ days, the second heating at $70{ }^{\circ} \mathrm{C}$ for 2 hours, and final heating at $100{ }^{\circ} \mathrm{C}$ for 1 hour [8]. In addition, natural rubber vulcanized by conventional methods can contain nitrosamines and allergen proteins that are harmful to health, especially downstream rubber products for health purposes, such as medical gloves, catheters and infusion tubes [4]. Based on this description, a new vulcanization technology is needed that can eliminate the shortcomings of conventional vulcanization.

One of the advanced technologies that can be used in the processing of polymers, such as natural rubber, is irradiation using gamma rays. Gamma-rays have been extensively used in last 50 years in polymers irradiation processes [9]. There are 160 gamma-rays processing units worldwide, $30 \%$ for polymers processing aiming to an optimization of materials properties [10-11]. Radiation vulcanization has been utilized to create a three dimensional design of rubber because of numerous benefits such as running at the ambient temperature, burning-through less energy, quicker, and naturally clean innovation [12-15]. Literature review by [4] stated that irradiation using gamma rays against natural rubber can reduce allergen proteins and nitrosamines so that health risks can be avoided.

This review study aims to examine how the irradiation vulcanization process, the radiation dose used, and its effect on the tensile strength properties of rubber products based on references from books and journals of national and international reputation. The results of the review can be used as a basis for future research and production of rubber.

\section{METHODOLOGY}

The approach used in this study is descriptive analysis by conducting a literature search on (i) the scheme of irradiation vulcanization stages; (ii) ratio of $\mathrm{G}_{\text {Values }}$ of crosslinking $(\mathrm{X}) /$ chain scission $(\mathrm{S})$ and the radiation dose used for certain rubber applications; and (iii) irradiation vulcanization effect to the rubber tensile strength properties.

\section{RESULT AND DISCUSSION}

Vulcanization is one of the important stages in the latex processing tapped from rubber trees. This process plays an awfully imperative function in the formation of the desired physical and chemical properties. In this process, the formation of chemical crosslinking from independent molecular chains increases 
elasticity and decreases the plasticity of rubber products.

The formulations commonly used to produce a rubber product consist of raw natural rubber latex, crosslinking agent, zinc oxide, stearic acid, accelerator, antioxidant, filler, and plasticizer. The main component of natural rubber that is commonly used is polyisoprene. This rubber is composed of isoprene monomor [6]. Chemical formula of polyisoprene is shown in Figure 1.

$$
\left[\mathrm{CH}_{2}^{\prime} \stackrel{\mathrm{CH}_{3}}{\mathrm{C}}=\mathrm{C}_{\mathrm{CH}_{2}}^{\prime \prime} f_{\mathrm{n}}\right.
$$

Figure 1. Polyisoprene Chemical Formula

In the vulcanization stage, the isoprene monomers are connected to each other using a crosslinking agent. The crosslinking agents commonly used in conventional vulcanization are sulfur and peroxides [6]. Vulcanization is carried out by heating three times, namely heating at $40-50{ }^{\circ} \mathrm{C}$ for $2-3$ days, the second heating at $70{ }^{\circ} \mathrm{C}$ for 2 hours, and final heating at $100{ }^{\circ} \mathrm{C}$ for 1 hour [8]. The preheating and the second are aimed at making a pre-vulcanized compound, while the final heating is a refinement stage. The reaction of polyisoprene and sulfur in conventional vulcanization is shown in Figure 2. In other, the chemistry of unaccelerated vulcanization is disputable. Numerous moderate reactions happen over the lengthy vulcanization duration. Researchers [16] thought that the mechanisms embroiled free radicals such in Figure 3.

A large variety of crosslinking methods has been developed for crosslinking of rubbers. The primary rubbers such as butadiene rubber, isoprene rubber, acrylonitrilebutadiene rubber, and styrene-butadiene rubber are vulcanized with sulfur (Table 1). Sulfur crosslinking of rubbers has been done for more than 100 years and has been continuously refined [6]. If there is a combustion reaction to rubber products, $\mathrm{SO}_{\mathrm{x}}$ gas will be produced. $\mathrm{SO}_{\mathrm{x}}$ gas is one of the gases that contribute to the greenhouse effect and can cause acid rain (acidification impact).

Table 1. Rubbers Major Crosslinking Methods

\begin{tabular}{ll}
\hline Rubber & Crosslinking agent \\
\hline Natural rubber & Sulfur \\
Isoprene rubber & Sulfur \\
\hline
\end{tabular}

\begin{tabular}{ll}
\hline $\begin{array}{l}\text { Styrene-buttadiene rubber } \\
\text { Acrylonitrile-butadiene }\end{array}$ & Sulfur \\
rubber & Sulfur \\
Isobutylene-isoprene rubber & Sulfur \\
Silicone rubber & Peroxide \\
$\begin{array}{l}\text { Ethylene-propylene-diene } \\
\text { rubber }\end{array}$ & Sulfur, Peroxide \\
\hline
\end{tabular}<smiles>[R12]C(C)C(C)C=CC#C[C@@H](C)C(C)=C[C+][SbH2]</smiles>

Rubber

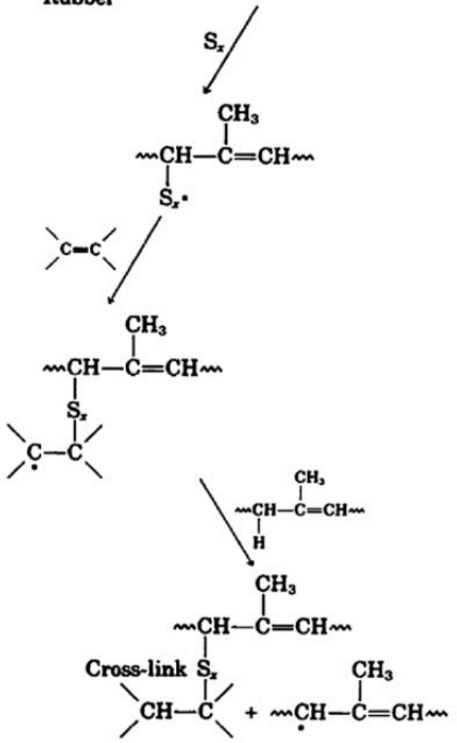

Figure 2. Reaction of vulcanization by sulfur without accelerator [16]

Dithiocarbamates are added during conventional vulcanization reactions to accelerate the vulcanization process. Other accelerator compounds that are commonly used are morpholino (di) thiobenzo-thiazole, dithiomorpholine, tetramethylthiuram disulfide, zinc dimetihldithiocarbamate [17]. These materials can form 4-nitroso morphine and dimethylnitrosamine. Both of these nitrosamines are elements of carcinogens that are harmful to health [4].

The mechanical strength (such as resistance to ripping and the tensile strength) of rubber can be increased by adding fillers, such as black carbon and precipitated silica. A plasticizer also needs to be added to the rubber mixture to enhance the deformability. Their role at low tiers is to help within the fillers deployment. At higher quantities they diminish viscosity of uncured compound, frequently reduce compound fee, lessen vulcanizate rigidity (toughness), and in a few instances enhance low temperature adaptability. 
Additionally they enhance steam in molding and extrusion by producing the uncured compound less elastic and diminishing friction and viscosity. One of the primary sources of plasticizers is aromatic petroleum oils [6].

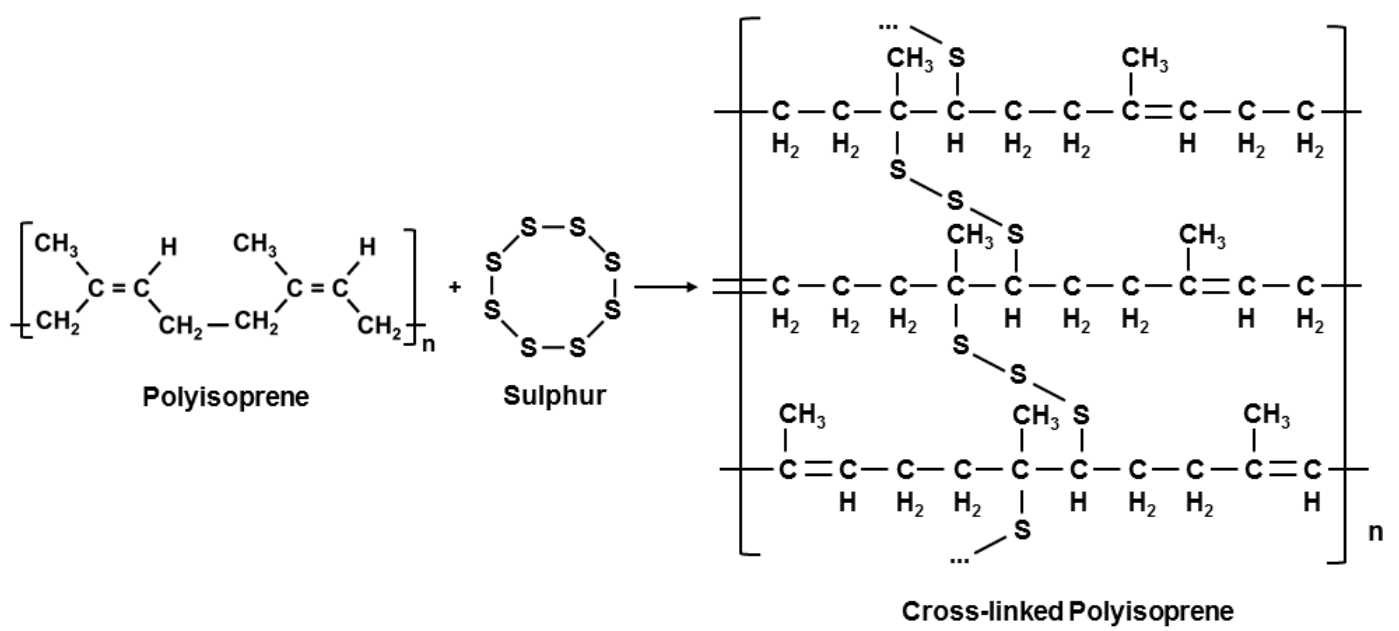

Figure 3. Conventional Vulcanization Reaction using Sulfur [4]

\section{Radiation Vulcanization}

Polymer processing using radiation entails conquering the polymers to the irradiation, generally in a non-stop mode, for polymers modification to enhance characteristics for manufacturing goal. For the objective of radiation polymer properties modification, the major irradiating sources consist of electron beams, gamma rays, and Xrays. Co-60 is one of radioactive isotopes used for producing gamma rays. Compared to electron beams and X-rays, gamma rays have advantages when viewed from the equipment side, such as easy to operate and maintain [6].

Radiation in latex will cause free radical formation and crosslinking between polyisoprene chains [8]. According to [6], in principle the polymer crosslinking scheme consists of the radical formation, initiation, propagation, and termination stages (Figure 4).

According to croslinking principle in Figure 4, the author tries to predict the reaction mechanism that occurs in the vulcanization process of polyisoprene rubber using gamma radiation as shown in Figure 5.
When polyisoprene is exposed to gamma radiation, the first step that occurs is the formation of radicals. The correlation of radical accumulation as a function of radiation dose to natural rubber is shown in Figure 6 [18]. Radical yield is the same for raw and for crosslinked rubber [11]. In this scheme, the authors predict that there are two types of radicals formed, namely the $\mathrm{H}^{*}$ radicals and the polyisoprene radicals themselves. In this scheme too, the authors foresee that radicals are formed thru the $\mathrm{C}-\mathrm{H}$ side chain dissociation. According to [6], free radicals are made either thru the $\mathrm{C}-\mathrm{H}$ side chain dissociation or thru the primary polymer chain scission.

\begin{tabular}{lll} 
Radical formation & $\mathrm{M}$ & \multicolumn{1}{c}{$\mathrm{X}^{*}$} \\
Initiation & $\mathrm{X}^{*}+\mathrm{M}$ & $\rightarrow \mathrm{XM}^{*}$ \\
Propagation & $\mathrm{XM}^{*}+{ }_{\mathrm{n}} \mathrm{M}$ & $\rightarrow \mathrm{XM}_{\mathrm{n}}{ }^{*}$ \\
Termination & $\mathrm{XM}_{\mathrm{n}}{ }^{*}+\mathrm{XM}_{\mathrm{m}}{ }^{*}$ & $\rightarrow \mathrm{P}$
\end{tabular}

Figure 4. Polymer Crosslinking Scheme ( $\mathrm{M}=$ Polymer, $*=$ Radical, $\mathrm{P}=$ Crosslinked Polymer) [6] 
Radical formation:
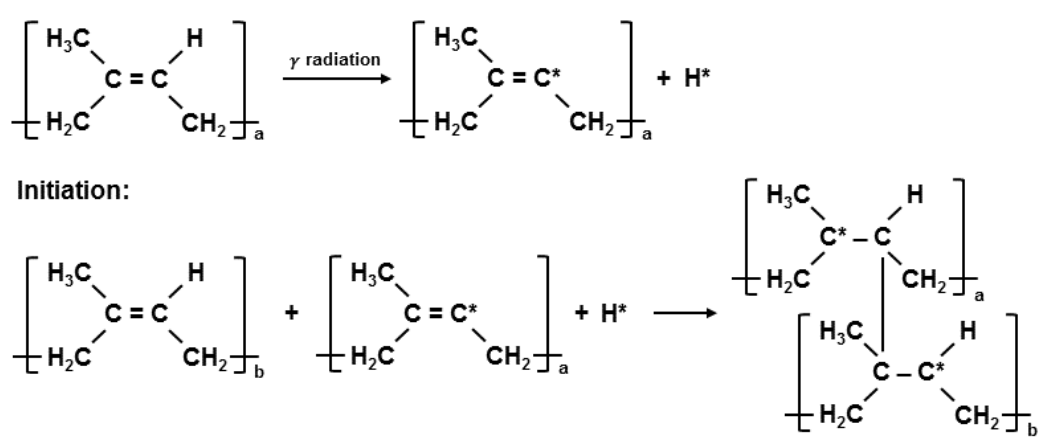

Propagation:

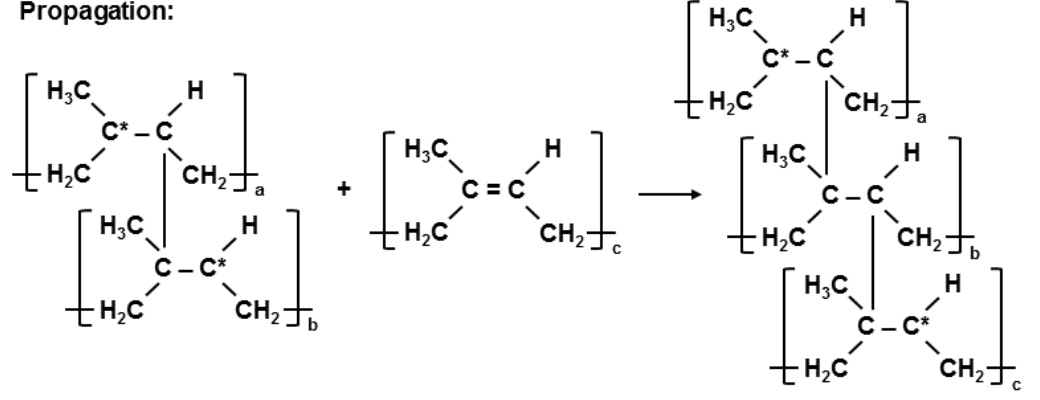

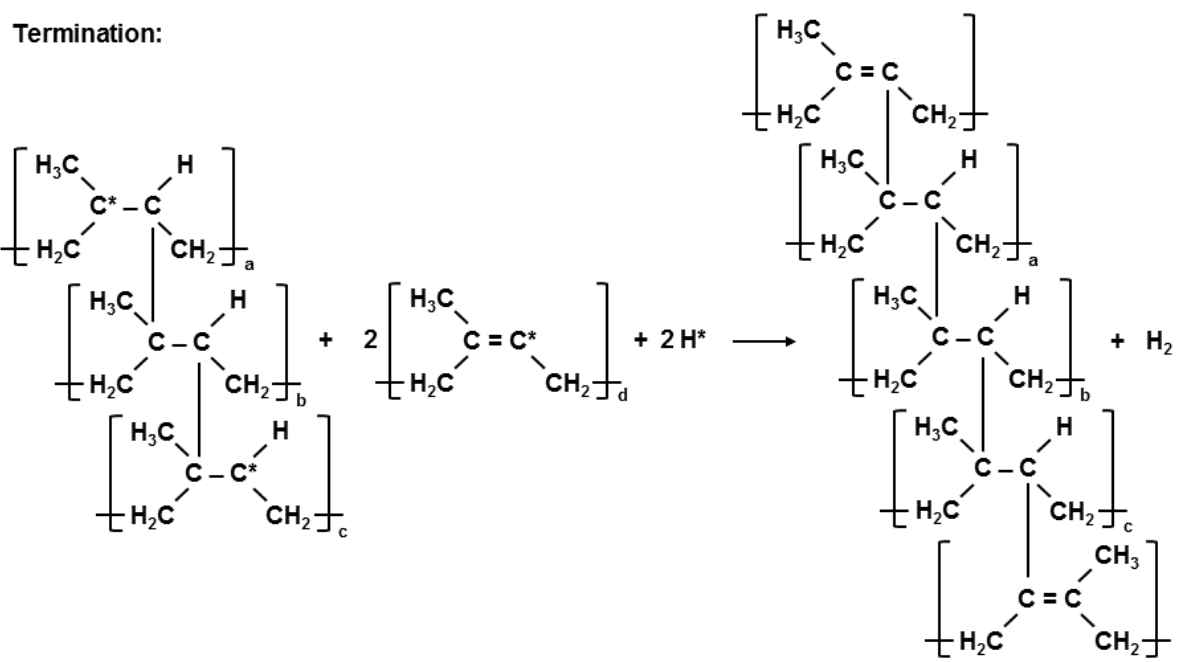

Figure 5. Prediction of Vulcanization Reactions using Gamma Radiation

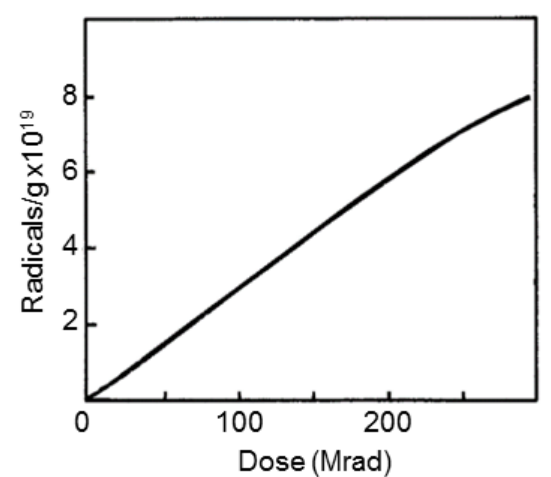

Figure 6. Radical yields in natural rubber on $\gamma$ radiation in vacuo at $77 \mathrm{~K}[18]$
The radicals formed will initiate other polymer chains to become radicals through the initiation stage. The radicals from chain $a$ of polyisoprene attack other chains to form bonds between $\mathrm{C}$ atoms of the two chains. The $\mathrm{H}^{*}$ radical again binds to the $\mathrm{C}$ atom of the chain $a$ of polyisoprene so that what is formed is the polyisoprene radical in the two chains. Polyisoprene chains will continue to cross-link with each other through the propagation stage so that more cross-links are produced than at the initiation stage. The cross-linking reaction stops when the polyisoprene chain in the propagation stage reacts with the polyisoprene radical or $\mathrm{H}^{*}$ radical at the radical formation stage. In this 
scheme, the authors predict that polyisoprene at the propagation stage reacts with polyisoprene radicals at the initiation stage and the $\mathrm{H}^{*}$ radicals form $\mathrm{H}_{2}$ gas. According to [19-21], approximately $98 \%$ of the gas generated through polyisoprene and natural rubber radiolysis comprise of hydrogen.
$\mathrm{H}$ atoms produced by $\mathrm{C}-\mathrm{H}$ bond scission often carry considerable kinetic energy and thus are able to abstract another hydrogen in their immediate vacinity yielding $\mathrm{H}_{2} \quad$ [18]. The approximate chemical formula for the cross-linked polyisoprene is shown in Figure 7.

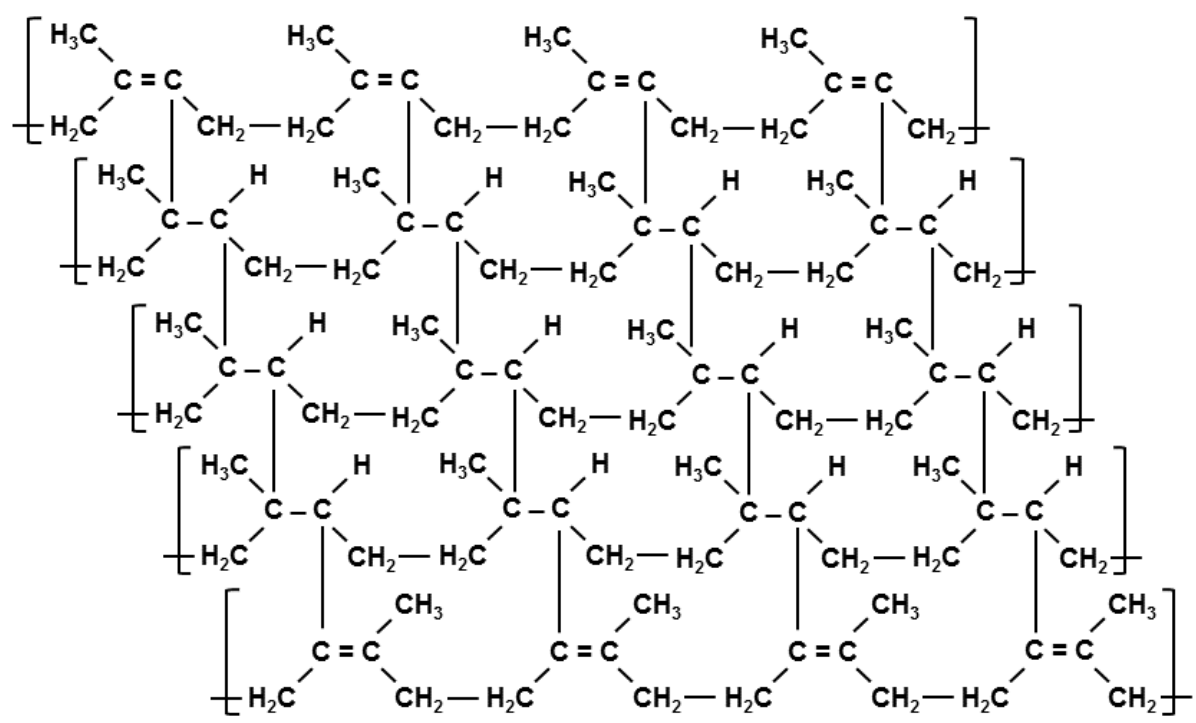

Figure 7. Prediction of Crosslinked Polyisoprene

The prevulcanization by irradiation of latex of natural rubber has additionally been a topic of research [22]. The mechanism of crosslinking is not yet completely caught on however the water seemingly performs a main part in it. The latex particles coarsening and the rubber molecules crosslinking is generated thru the irradiation process [18].

\section{Irradiation Dose}

As radiation from a gamma ray reacts with a polymer material, the polymer material absorbs the energy and generates active species such as radicals, thus causing different chemical reactions. The basic processes that are the outcomes of such reactions involve [6]:

- Crosslinking, where polymer chains are interconnected and a network forms

- Chain scission, where the polymer's molecular weight is lessened by chain splitting

- Oxidation, where the polymer molecules react via peroxide radicals with oxygen (chain scission and oxidation sometimes occur concurrently)

- Long-chain branching, where polymer chains are connected, but there is not yet a three-dimensional network built

- Grafting, where a new monomer is polymerized and grafted onto the base polymer chain

For instance, when bromobutyl rubber is subjected to higher ionizing radiation, chain scission and crosslinking occur at the same time. Scission and crosslinking were retained for low doses and degradation was retained for high doses [23].

Different polymers provide different radiation effects, specifically when it comes to chain scission vs. crosslinking. Radiation chemists typically use a parameter called the $G$ value to measure the chemical yield resulting from radiation [6]. The $\mathrm{G}$ value is determined as the radiation's chemical yield in the number of molecules reacted per $100 \mathrm{eV}$ of energy absorbed. For some of the typical polymeric materials irradiated at ambient temperature 
lacking oxygen, Table 2 shows the $\mathrm{G}$ values for chain scission $\mathrm{G}(\mathrm{S})$ and crosslinking $\mathrm{G}(\mathrm{X})$ [2425]. For crosslinking, materials with $G(S): G(X)$ ratios $<1.00$ are preferred. Materials with a ratio of $G(S): G(X)>1.00$ tend to suffer further degradation. Materials with both low $\mathrm{G}(\mathrm{S})$ and $\mathrm{G}(\mathrm{X})$ values are more prone to radiation [26].

Both $G(X)$ and $G(S)$ are enhanced as the dose increases in comparison to the radiation dose. Fortunately, with increasing dose, G(S) for a polymer usually increases more than $G(X)$ does. Three separate circumstances for the association between radiation dose and polymer molecular weight (MW) can therefore be established, as shown in Figure 8 [26]. If a polymer's $G(X)$ is much more than $G(S)$, due to continuous crosslinking, the MW tends to increase continuously, but the MW will level off because $G(S)$ will happen rapidly. $G(S)$ will finally catch up with $G(X)$ once $G(X)$ is higher, but not so much higher than $\mathrm{G}(\mathrm{S})$, and the MW should represent a pivotal point, with the main reaction moving from crosslinking to degradation. When $G(S)$ is greater than $G$, continuous degradation may happen $(\mathrm{X})$.

\begin{tabular}{lllll} 
Table 2. G Values for Chain Scission and Crosslinking for Certain Rubbers \\
\hline Rubber & Crosslinking G(X) & Scission G(S) & $\begin{array}{l}\text { Crosslinking } \\
\mathbf{G}(\mathbf{X})\end{array}$ & $\mathbf{G ( S ) : G ( X )}$ \\
\hline Natural rubber & $1.3-1.5$ & $0.1-0.2$ & $1.3-1.5$ & 0.14 \\
Polystyrene & $0.019-0.051$ & $0.0094-0.019$ & $0.019-0.051$ & 0.4 \\
Polybutadiene & 5.3 & 0.53 & 5.3 & 0.10 \\
Butyl rubber & $<0.5$ & $2.9-3.7$ & $<0.5$ & $>6$ \\
\hline
\end{tabular}

Minimum and maximum doses have to be calculated for practical industrial radiation production. To achieve the desired effect, the minimum dose is what is needed, and the maximum dose is where they become uneconomical or when adverse effects start to occur. (The cost of processing is normally proportional to the dose). Table 3 shows the approximate ranges of required radiation dose for various applications.

The dose rate, or the rapid delivery of the dose to the irradiated material, can also have a major impact on the outcome. For instance, higher dose rates are more beneficial towards crosslinking in the competition for oxidative degradation and crosslinking in air because less oxidation may happen in a shorter period (because of the oxygen diffusion control for). Gamma rays have a much lower dose rate than industrial electron beams, and when deciding between the two, the dose rate might be an important thing to consider.

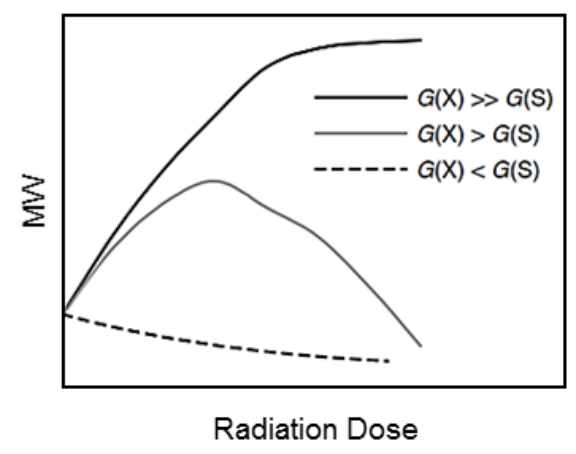

Figure 8 . Relation between radiation dose and polymer's MW [26]

Table 3. The number of doses needed for different applications

\begin{tabular}{ll}
\hline Application & Required Dose (kGy) \\
\hline $\begin{array}{l}\text { Prevulcanization of tires } \\
\text { Curing of coating, } \\
\text { composites, adhesives }\end{array}$ & $15-50$ \\
$\begin{array}{l}\text { Crosslinking of cables and } \\
\text { wires }\end{array}$ & $30-200$ \\
$\begin{array}{l}\text { Graft polymerization } \\
\text { Crosslinking of polymers } \\
\text { foams }\end{array}$ & $50-200$ \\
\hline
\end{tabular}

Research by [27] obtained using 5 phr nbutyl acrylate (nBA) with potassium hydroxide as a stabilizer, the optimal vulcanization dose is $15 \mathrm{kGy}$. Together with carbon tetrachloride and the sensitizer system $\mathrm{nBA}$, hydrogen peroxide will lower the vulcanization dose to $10 \mathrm{kGy}$ [28]. Research by [29] found that N-BA alone is the best way to improve radiation crosslinking, which increases the irradiated latex film's tensile properties. The tensile strength increases with an increase in the radiation dose. The best conditions for irradiation were found to be 12 $\mathrm{kGy}$ of radiation dose, $5 \mathrm{phr} \mathrm{nBA}$ and 30-40 min of mixing time. There is no improvement in tensile strength after this dose.

The dose increase from 50 to $250 \mathrm{kGy}$ led to an increase in the cross-link density of the irradiated ultrafine rubbers (UFRs), thus enhancing the thermal stability of the rubber products obtained. In addition, due to the 
additional development of C-C networks between the main chains of the various rubber molecules, the increase in thermal stability of radiation crosslinked UFRs was achieved [30].

Research by [23] about radiation effects on bromobutyl rubber found that after irradiation occurs a reduction in tensile strength values, even for low doses such as $5 \mathrm{kGy}$, indicating the prevalence of chain scission with consequent mass molar reduction, because smaller polymeric chains break easier. For doses from 5 to $25 \mathrm{kGy}$ it can be observed scission and crosslinking simultaneous events. For doses above $50 \mathrm{kGy}$ it is observed the prevalence of chain scission and further polymeric chain degradation.

Another analysis by [31] regarding gamma radiation on natural rubber/styrene butadiene rubber blends showed that for doses up to $150 \mathrm{kGy}$ the crosslinking mechanism was the dominant one, while apparently, the degradation mechanism has occurred for doses greater than $150 \mathrm{kGy}$.

\section{Rubber Tensile Strength Properties}

With the creation of cross-links, the mechanical and physical properties of latex of natural rubber will improve, such as increased stiffness and tensile strength, increased solvent resistance (solvent), decreased elongation, and heat resistance (thermal deformation).

Tensile strength and modulus, measured by stress-strain tests, are the most widely recorded physical properties of radiation-cured natural rubber and compounds made of it. The tensile strength of the vulcanized radiation cured gum is compared with that of its sulfur and peroxide cured analogs in Figure 9. It is obvious that for a complete cure, large doses are needed. The level of dose taken to fulfill maximum tensile strength ranges from 20 to 50 Mrad. There is susceptibility to these and scission processes after exposure. The healing dose is decreased and higher tensile strength values are observed when crosslink promoters such as dichlorobenzene are used [18].

In contrast to gamma radiation, as exposure is done in air, much greater tensile strength and ultimate elongation are obtained with high-energy electrons. However, As antioxidants are introduced to the compound, the variations decrease [32]. Simultaneous exposure to ionizing radiation, oxygen, and ozone and the protection provided by some antioxidants can also be related to this effect due to splits arising from various time periods. For radiation curing, the maximum tensile strength retention at elevated temperatures is greater than for chemically vulcanized natural rubber [3233].

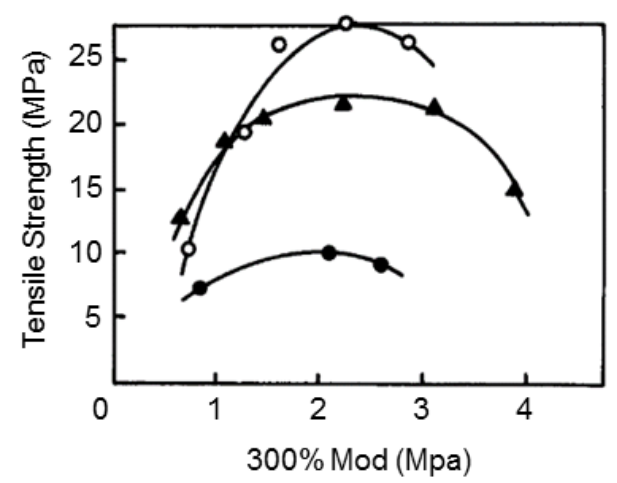

Figure 9. Tensile strength of vulcanizates produced from purified natural rubber, (o) sulfur, $(\boldsymbol{\Delta})$ peroxide, $(\bullet)$ electron irradiation in $\mathrm{N}_{2}$ at $0.25 \mathrm{Mrad} / \mathrm{sec}$ [18]

Radiation vulcanization has been used to form a three dimensional structure of rubber. As a result, the vulcanized rubber offers excellent mechanical and thermal properties and high stability [34-35].

\section{Radiation Crosslinking Versus Sulfur Crosslinking}

The tensile strength at break $(T b)$ of radiation vulcanizate (crosslinked rubber) has long been presumed to be lower than that of sulfur vulcanizate or peroxide vulcanizate, as shown in Figure 10 [36]. The lower $T b$ of radiation crosslinked rubber was clarified by the crosslinking structure. Polysulfudic (170 $\mathrm{kJ} / \mathrm{mol})$, disulfidic $(220 \mathrm{~kJ} / \mathrm{mol})$ and monosulfidic $(270 \mathrm{~kJ} / \mathrm{mol})$ crosslink bond energies are lower than the crosslinks of carboncarbon $(360 \mathrm{~kJ} / \mathrm{mol})$.

By splitting the $S-S$ bonds and generating new S-S bonds under deformation, the weak S$\mathrm{S}$ crosslinks are able to eliminate local stresses in the network. In the case of splitting under strong strain, this is called self-regenerating. On the other hand, low elongation may break down the highly stressed chains of tight $\mathrm{C}-\mathrm{C}$ crosslinks. The stress will then be transmitted to neighboring chains, which in turn will break, 
leading to a disastrous rupture of the network very quickly. The low $\mathrm{Tb}$ of the vulcanization of radiation thus appears inherent. However, after changing the polysulfudic bond to monosulfidic and disulfidic bonds via the triphenylsulfine reaction, very little change in $\mathrm{Tb}$ was observed [37]. Furthermore, no reports of mechanical breakage of polysulfide crosslinks was identified at ambient temperature [38]. Eventually, the variations in the properties of the various vulcanizing systems are clarified by the variations in the network structure heterogeneity [36]. For example, scanning electron micrographs of cryofracture surfaces can be used to observe heterogeneity. The crosslinks were not distributed uniformly in the sulfur vulcanized rubber networks. For radiation vulcanizate, a somewhat more surface is found than for sulfur vulcanizate. With an improvement in network homogeneity, tensile properties appear to diminish. Figure 11 indicates another vulcanization model [37]. The accelerator system for sulfur vulcanization produces a heterogeneous network structure where phases B of high crosslink density domains are incorporated in phases $\mathrm{A}$ of the rubber network matrix. Compared with sulfur vulcanizate, peroxide crosslinking provides a more homogeneous random network structure. The higher $T b$ is contributed by the $\mathrm{B}$ phase [39].

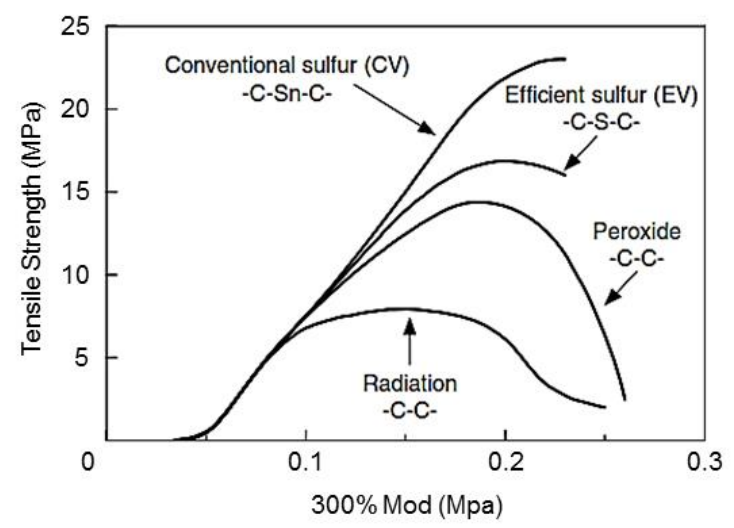

Figure 10. Isoprene rubber tensile strength, crosslinked by various methods [36]

\section{Radiation Crosslinking Versus Peroxide Crosslinking}

Crosslinking is based on a radical mechanism, either by radiation or peroxide. The degree of isomerization of peroxide crosslinked natural rubber by the cis-trans chain is greater than that of radiation crosslinked natural rubber at the same crosslink density level [40]. As shown in Figure 9, the tensile strength of radiation vulcanizate is much smaller than peroxide vulcanizate.

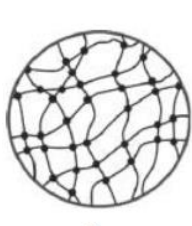

a

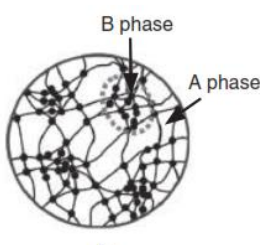

b

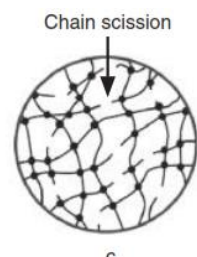

c
Figure 11. Micrographs of Natural Rubber Crosslinked by Hypothesized Network by (a)

Peroxide, (b) Sulfur, and (c) Radiation [37]

It is assumed that the lower $T b$ of radiation vulcanization is due to during irradiation scissions of chain of rubber molecules [41]. Additional rubber degradation is also affected by radiation-induced oxidation of rubber and oxidation by the ozone attack produced during irradiation. Subsequently, the network structure of radiation vulcanizate, as shown in Figure 11, has many defects. Improving radiation crosslinking and eliminating oxygen and ozone will avoid radiation degradation, such that sulfur vulcanizate is not preferable to the $\mathrm{Tb}$ of radiation-vulcanized rubber.

The approaches for enhancing radiation crosslinking could be defined as follows [26]:

1. Incorporation with filler

2. Increasing the possibility of polymer radical recombination by polyfunctional monomer addition, plasticizer addition, hightemperature irradiation, and compression

3. Increasing the amount of polymer radicals in the amorphous area by incorporating heat treatment with post-irradiation and sensitizer.

\section{CONCLUSION}

Radiation in latex of natural rubber will cause free radical formation, crosslinking, and chain scission between polyisoprene chains, and also produce mostly $\mathrm{H}_{2}$ gas. For crosslinking, materials with $\mathrm{G}(\mathrm{S}): \mathrm{G}(\mathrm{X})$ ratios $<1.00$ are preferred. The dose increase till certain dose led to an increase in the cross-link density of the irradiated rubbers, while apparently, the degradation mechanism has occurred for doses greater than optimum doses. The tensile 
strength at break of radiation vulcanizate has long been presumed to be lower than that of sulfur vulcanizate or peroxide vulcanizate. The approaches for enhancing radiation crosslinking could be defined by incorporation with filler, increasing the possibility of polymer radical recombination, and increasing the amount of polymer radicals.

\section{DAFTAR PUSTAKA}

1. R. A. Putranto. (5 January 2021). Menguak rahasia penyakit kering alur sadap (KAS) pada tanaman karet menggunakan teknik analisis ekspresi gen debit tinggi. Available: https://www.iribb.org/images/stories/artike 1/IBRIEC_01010406_RAP_final.pdf

2. A. B. Parhusip, "Potret karet alam indonesia," Economic Review, vol. 213, pp. 2-3, 2008

3. M. Chafid, Outlook Karet 2020: Pusat Data dan Sistem Informasi Pertanian Sekretariat Jenderal-Kementerian Pertanian Indonesia, 2020.

4. W. Andriyanti, Darsono, and W. Faisal, "Kajian Metode Vulkanisasi Lateks Karet Alam Bebas Nitrosamin dan Protein Alergen," in Prosiding PPI-PDIPTN 2010 Pustek Akselerator dan Proses BahanBATAN, 2010, pp. 161-169

5. Balittri. (11 January 2021). Keunggulan Karet Alam Dibandingkan Karet Sintetis. Available: http://perkebunan.litbang.perta nian.go.id/keunggulan-karet-alam-dibandin g-karet-sintetis/

6. A. Ciesielski, An Introduction To Rubber Technology: Rapra Technology Limited, 1999.

7. W. Hofmann, Rubber Technology Handbook: Hanser Publishers, 1989.

8. M. Utama, Teknologi Lateks Alam Radiasi: Solusi Problema Produksi Barang Karet; Pusat Pengembangan Informatika NuklirBadan Tenaga Nuklir Nasional, 2007.

9. International Atomic Energy Agency (IAEA), Gamma Irradiator for Radiation Processing (Brochure): IAEA, 2000.

10. International Atomic Energy Agency (IAEA), Directory of Gamma Processing Facilities in Member Stats. IAEA$D G P F / C D$ : IAEA, 2004.

11. G. G. A. Bõhm and J. O Tveekrem, "The radiation chemistry of elastomers and its industrial applications," Rubber Chemistry and Technology, vol. 55, pp. 575-668, 1982

12. M. R. Abadchi and A. Jalali-Arani, "The use of gamma irradiation in preparation of polybutadiene rubber nanopowder; Its effect on particle size, morphology and crosslink structure of the powder," Nucl. Instrum. Methods Phys. Res. B, vol. 320, pp. $1-5,2014$

13. R. Giri, K. Naskar, and G. B. Nando, "Effect of electron beam irradiation on dynamic mechanical, thermal and morphological properties of LLDPE and PDMS rubber blends," Radiat. Phys. Chem., vol. 81, pp. 1930-1942, 2012

14. M. N. Mali, A. A. Arakh, K. A. Dubey, and S. T. Mhaske, "Influence of triallyl cyanurate as coagent on gamma irradiation cured high density polyethylene/reclaimed tire rubber blend," Radiat. Phys. Chem., vol 131, pp. 66-72, 2017

15. B. Tian, W. Dong, and Y. Liu, "Grafting poly(vinyl alcohol) onto polybutadiene rubber latex particles by pre-irradiation," Radiat. Phys. Chem., vol. 135, pp. 81-87, 2017

16. E. H. Farmer, "Certain fundamental concepts relating to non-polar mechanisms in oleflnic systems," Journal of the Society of Chemical Industry, vol. 66, no. 3, pp. 8693, 1947

17. J. E. Mark, B. Erman, and C. M. Roland, The Science and Technology of Rubber Fourth Edition: Academic Press, 2013.

18. Z.N. Tarasova, M.S. Fogel'son, V.T. Kozlov, A.I. Kashlinskii, M.Ya. Kaplunov and B.A. Dogadkin, "ESR study of the radiation vulcanization of rubber in the presence of sulphur and hexachloroethane," Vysokomol. Soedin., vol. 4, no. 8, pp. 12041209, 1962

19. S. M. Miller, M. W. Spindler, and R. L. Vale, "Use of dimaleimides as accelerators for the radiation-induced vulcanization of hydrocarbon polymers. Part II. Synthetic rubbers and saturated polymers," Journal of Polymer Science Part A: General Papers, vol. 1, no. 8, pp. 2537-2549, 1963

20. Petrov, Ya., Karpov, V.L., and Sovesk, T.V., 1958, po Red. Khim. Acad. of Sci. of USSR 279.

21. D. T. Turner, "Radiation crosslinking of rubber: Yields of hydrogen and crosslinks," Polymer, vol. 1, pp. 27-40, 1960 
22. H. Ambroz, "Some aspects of $\gamma$-radiolysis of polyisoprene in the form of natural rubber latex," Journal of Polymer Science: Polymer Symposia, vol. 42, no. 3, pp. 13391345, 2007

23. S. R. Scagliusi, E. C. L. Cardoso, C. A. Pozenato, and A. B. Lagão, "Degrading radiation effects on properties of bromobutyl rubber compounds," in 2013 International Nuclear Atlantic Conference INAC 2013, 2013, pp. 1-8

24. Y. Tabata, Y. Ito, and S. Tagawa, $C R C$ Handbook of Radiation Chemistry: CRC Press, 1991.

25. J. Mark, Physical Properties of Polymers Handbook: AIP Press, 1996.

26. K. Makuuchi and S. Cheng, Radiation Processing of Polymer Materials and Its Industrial Applications: John Wiley \& Sons, Inc., 2012.

27. C. Zhonghai and K. Makuuchi K, "n-Butyl acrylate as a sensitizer for radiation vulcanization of natural rubber latex," in Proc. Int. Syrup. Radiat. Vulcanization of Natural Latex, 1989, pp. 89-228

28. Y. S. Soebianto and F. Sundardi, "Effect of hydrogen peroxide on radiation vulcanization of natural rubber latex sensitized with carbon tetrachloride and nbutyl acrylate," in Proc. Int. Syrup. Radiat. Vulcanization of Natural Rubber Latex, 1989, pp. 89-228

29. M. E. Haque, N. C. Dafader, F. Akhtar, and M. U. Ahmad, "Radiation dose required for the vulcanization of natural rubber latex," Radiant. Phys. Chem., vol. 48, no. 4, pp. 505-510, 1996

30. R. Taewattana, C. Jubsilp, P. Suwanmala, and S. Rimdusit, "Effect of gamma irradiation on properties of ultrafine rubbers as toughening filler in polybenzoxazine," Radiation Physics and Chemistry, vol. 145, pp. 184-192, 2018

31. A. B. Moustafa, R. Mounir, A. A. El Miligy, and M.A. Mohamed, "Effect of gamma irradiation on the properties of natural rubber/styrene butadiene rubber blends," Arabian Journal of Chemistry, vol. 9, no. 1, pp. 124-129, 2016

32. D. J. Harmon, "Radiation vulcanization of elastomers," Rubber Age, vol. 86, pp. 251261, 1959

33. H. E. Adams and B. L. Johnson, "Cross Linking in Natural Rubber Vulcanizates,"
Ind. Eng. Chem., vol. 45, no 7, pp. 15391546, 1953

34. S. Ahmed, A. A. Basfar, M. M. Abdel Aziz, "Comparison of thermal stability of sulfur, peroxide and radiation cured NBR and SBR vulcanizates," Polym. Degrad. Stabil., vol 67, pp. 319-323, 2000

35. A. A. Basfar, M. M. Abdel-Aziz, S. Mofti, "Influence of different curing systems on the physico-mechanical properties and stability of SBR and NR rubbers," Radiat. Phys. Chem., vol. 63, pp. 81-87, 2002

36. J. H. A. Grobler and W. J. McGill, "Effect of network heterogeneity on tensile and tear strengths of radiation, peroxide, efficient and conventional cured polyisoprene," Journal of Polymer Science: Part B: Polymer Physics, vol. 32, pp. 287-295, 1994

37. J. Lal, "Effect of crosslink structure on properties of natural rubber," Rubber Chemistry and Technology, vol. 43, pp. 664-686, 1970

38. A. V. Tobolsky and P. F. Lyons, "Tensile strength of rubbers," Journal of Polymer Science: Part A2: Polymer Physics, vol. 6, pp. 1561-1566, 1968.

39. Y. Ikeda, Y. Yasuda, K. Hijikata, M. Tosaka, and S. Kohjiya, "Comparative study on strain-induced crystallization behavior of peroxide crosslinked and sulfur crosslinked natural rubber," Macromolecules, vol. 41, pp. 5876-5884, 2008

40. D. P. Patterson and J. L. Koenig, "Solidstate C NMR characterization of irradiation crosslinked natural rubber," Applied Spectroscopy, vol. 41, pp. 441-446, 1987

41. G. G. A. Bohm, M. Detrano, D. S. Pearson, D. R. Carter, "A comparison of the physical properties of radiation and sulfur-cured poly(butadiene-co-styrene)," Journal of Applied Polymer Science, vol. 21, pp. 31933209, 1977 
Jurnal Forum Nuklir Volume 15, Nomor 1, Mei 2021 